\title{
A Methodological Review of Fashion Marketing Studies
}

\begin{abstract}
In this study, fashion marketing studies were examined in terms of method in line with the paradigms adopted in the social sciences. Firstly, explanations of the concepts were presented in order to make sense of the nature of positivist, post-positivist paradigms and quantitative, qualitative research. Then, theses written in the field of fashion marketing in The Council of Higher Education (CoHE) National Thesis Center were analyzed by content analysis. These analyzes were carried out to show the distribution of theses by years in terms of paradigm. In addition, the data collection tools, data analysis techniques and research patterns utilized in the studies were examined, and the techniques that were widely adopted and started to be adopted were explained. According to the findings, quantitative studies are widely used in fashion marketing studies and it has been observed that the use of qualitative and mixed studies have increased in recent years. In quantitative studies, questionnaires and statistical analyzes are widely used and causal research is often applied. In qualitative studies, different data collection and analysis methods are adopted in accordance with the characteristics and design of the research. It has been concluded that mixed studies are mostly designed by adopting multiple methods in accordance with the purpose.
\end{abstract}

Keywords: Method, paradigm, quantitative research, qualitative research, fashion marketing studies.

\section{Moda Pazarlama Çalışmalarının Metodolojik Bağlamda İncelenmesi}

\section{$\ddot{\mathbf{O z}}$}

Bu çalışmanın amacı moda pazarlama çalışmalarını, benimsenen paradigma ve yöntem bakımından inceleyerek, araştırmacılara yönteme dair bir çerçeve sunmaktır. Bu amaçla öncelikle, pozitivist ve post-pozitivist paradigmalara dair kavramsal açıklamalara yer verilmiştir. Sonrasında ise Ulusal Tez Merkezi'nde bulunan moda pazarlama tezleri içerik analizi ile incelenmiş, paradigma bakımından yıllara göre dă̆llımları gösterilmiştir. Ayrıca çalışmalarda yararlanılan veri toplama araçları, veri analiz teknikleri ve araştırma desenleri incelenerek yaygın benimsenen ve yeni benimsenmeye başlanan teknikler açıklanmıştır. Sonuçlar incelendiğinde moda pazarlama çalışmalarında nicel araştırmaların sıklıkla kullanıldı̆̆ı, nitel ve karma araştırmaların kullanımının son yıllarda dikkat çekmektedir. Nicel çalışmalarda, anketler ve istatistiksel analizler yaygın olarak kullanılmakta ve araştırma deseni olarak da nedensel araştırmalar sıklıkla karşımıza çıkmaktadır. Nitel çalışmalarda, araştırmanın karakteristiğine ve desenine uygun biçimde farklı veri toplama teknikleri ve analizler kullanılmaktadır. Karma çalışmaların ise çoğunlukla, amacına uygun olarak, çoklu yöntemler benimsenerek tasarlandiğı görülmektedir.

Anahtar kelimeler: Yöntem, paradigma, nicel araştırma, nitel araştırma, moda pazarlama çalışmaları.

*ORCID Öğr. Gör. Dr. Kastamonu Üniversitesi Araç Rafet Vergili Meslek Yüksekokulu, hoztay@kastamonu.edu.tr 


\section{Genişletilmiş Özet}

Pazarlama yöneticileri, önemli kararlar vermeleri gereken durumlarda, sorunlarla karşılaştıklarında ya da olumlu ve istenen bir sürecin istikrarlı biçimde devam edebilmesi için pek çok bilgiye ihtiyaç duymaktadırlar. Moda pazarlama çabalarının da modanın sürekli değişen yapısı, modaya yüklenen anlamın değişmesi, tüketici tercihlerinin değişmesi gibi kendine özgü bazı karakteristikleri vardır. Hızlı moda, yavaş moda, sürdürülebilir moda, etik moda gibi yeni moda anlayışlarının ortaya çıkması ile tüketici davranışlarından, tedarik ve dağıtım süreçlerine, tasarım-üretim süreçlerinden tutundurma ve fiyatlandırmaya kadar pek çok uygulama alanında etkili kararlar verilebilmesi için doğru ve güvenilir bilgiye ulaşmak önemli hale gelmiştir. Bu gerçekler paralelinde moda pazarlama araştırmalarının önemi göz önünde bulundurulduğunda, yapılan çalışmaların yapısı önem kazanmaktadır.

Bilimsel araştırmaların çeşitli amaçlarla kullanımı söz konusudur. Bilimsel araştırmalarda keşfetmek, mevcut durumu tanımlamak, nedenselliği ortaya koymak gibi amaçlar söz konusu olabilir. Araştırmacı sosyal gerçekliği nasıl algıllyorsa o doğrultuda araştırma yöntemi benimser. Sosyal bilimlerde, olguların objektif biçimde değerlendirildiği pozitivist yaklaşım ve olguların içinde bulundukları sosyal gerçeklik ve ilişkilerin etkisiyle değerlendirilmesi gerektiğini ifade eden post-pozitivist yaklaşım olmak üzere iki paradigma söz konusudur. Benimsenen paradigma araştırmanın yöntemini de etkiler. Pozitivist yaklaşım nicel, postpozitivist yaklaşım ise nitel araştırmalarla çalışılmasını önerir. Araştırma probleminin işlevsel şekilde çözümlenebilmesi için hangi türden bir yöntemin belirlenmesi gerektiği oldukça önem kazanmaktadır. Pazarlama ve moda pazarlama araştırmalarında pozitivist yaklaşımı benimseyen nicel araştırmaların sıklıkla kullanıldığı görülmektedir. Ancak çalışma sonuçları göstermektedir ki son yıllarda post-pozitivist yaklaşıma dayanan nitel araştırmalar da kullanılmaya başlanmıştır. Nitel araştırmaların hem tek başına hem de nicel araştırmaları destekleyecek şekilde karma yöntemlerde kullanıldığı görülmektedir.

Yüksek lisans ve doktora tezleri ayrı ayrı incelendiğinde nicel çalışmaların baskın olduğu görülmektedir. Nicel anlayışla yazılmış moda pazarlama tezlerinde anket kullanımı ve veri analiz türü olarak da istatistiki yöntemler neredeyse bir norm haline gelmiş ve çalışmalarda sıklıkla kullanılmıştır. Araştırma deseni olarak ise durum ve olayların ne olduğunu açıklayan betimsel çalışmalardan yararlanıldığı gibi, değişkenler arası ilişkileri gösteren nedensel araştırmalar da tasarlanmıştır. Çalışmanın sonuçları göstermektedir ki moda pazarlama alanında nedensel araştırmalar betimsel araştırmalardan daha fazla tercih edilmiştir.

Bu çalışmanın sonuçları da göstermektedir ki, nicel araştırmalar moda pazarlama alanında hakim paradigma olmaya devam etmekle birlikte nitel ve karma araştırmalarda son yıllarda artış olduğu göz ardı edilemeyen bir gerçektir. Nitel araştırmalarda nicel araştırmalarda olduğu gibi norm haline gelmiş veri toplama araçları ve veri analiz türlerinden söz edilemez. Çalışmanın karakteristiği ve ortaya koymayı amaçladığı duruma göre farklı teknikler kullanılabilir. Nitel araştırmalarda veri toplama araçları olarak gözlem, görüşme, ikincil verilerden yararlanma gibi yöntemler söz konusudur. Yararlanılan analiz teknikleri ise, doküman analizi, içerik analizi, gösterge analizi, betimsel analiz ve tematik analizdir.

Nitel yöntemlerin kullanımındaki artışla ve her iki yöntem çeşidinin de güçlü ve zayıf yanları olduğu varsayımı ile her iki yöntemin birbirinin tamamlayıcısı niteliğinde olan karma yöntemler karşımıza çıkmaktadır. Bu tarz araştırma desenleri de hem yüksek lisans hem doktora tezlerinde ilk kez 2009'da kullanılmış olmakla birlikte önemi anlaşılmaya başlanmış ve son yıllarda kullanımında artış söz konusu olmuştur.

Nitel araştırma yöntemleri, nicel araştırmacılar ve pozitivist düşünürler tarafindan sıklıkla eleştirilere uğrasa da sosyal bilimler alanında söz konusu olan boşlukların doldurulması, derinlemesine anlamlar çıkarılması, süreçlerin tanımlanması, olayların arkasındaki esas nedenlerin ortaya çıkarılması ve benzer durumlarda sıklıkla kullanılmaya başlanan yöntemlerdir. Ayrıca tek başına kullanılabildiği gibi nicel yöntemlerin eksik yanlarını tamamlayaııı bir işlevle kullanımı da bilim üretme noktasında benimsenebilecek yollardan bir tanesidir. Bu sonuçlar doğrultusunda sosyal bilimler alanında çalışan araştırmacılara, ele alınan problemin çözümü noktasında metodolojik olarak sınırlı kalmamaları önerilmektedir. Alternatif anlayışları da göz önünde bulundurarak değerlendirmeler yapmaları ve en iyi problem çözme tekniğini belirlerken problemin karakterine uygun tercihte bulunmaları önerilmektedir. 


\section{Introduction}

Marketing managers have to make decisions that can result in huge financial gains or losses. Products that do not sell after launch, problems in distribution channels, etc. situations are some of the problems that managers face and have to solve. In addition, the time required to make decisions has been shortened and the importance of the decisions has increased because of situations such as competitive pressure on a global scale, shortening of product life periods, the necessity to keep up with the developing technology (Gegez, 2010: 3). In the 21st century, many retailers, especially in the field of fashion, have restructured their competitive advantage focus from price advantage to respond to the demands of consumers quickly and creating fashion trends (Barnes and Lea-Greenwood, 2006: 260). Because of this situation new concepts such as fast fashion has emerged. As the exact opposite of this, concepts such as slow fashion and sustainable fashion are practices adopted by today's fashion consumers. All this has increased the importance of accessing fast and accurate information. This also increased the need for marketing research (Gegez, 2010: 3).

Science is systematic information. In addition, it is both the information itself and a structure that produces the information. While the theories, laws and principles developed to explain facts and relationships, are the information itself, the ways of producing information can be defined as a method (Kaptan, 1995: 7). Science is accumulated information that represents an integrity with rational and factual relationships. The information that composes science should be systematically classified and important relationships should exist between them (Güven, 1996: 2).

Scientific research is basically four different types: exploratory, explanatory, descriptive and evaluative. Exploratory research is designed to find new information in areas where previous scientific studies are inadequate and to explore previously missed or unknown topics. Explanatory research is done to investigate the cause of the events. Descriptive research is done to understand what is happening in the research area. Descriptive studies include numerical data, statistical information and descriptive explanations. Evaluation studies can be defined as researches aiming to solve a problem in a particular subject, by examining the process in this subject and trying to solve the problem in this field (Güler et al., 2013: 21).

In social sciences, researchers do not act objectively when deciding to the method. How the researcher perceives social facts determines the research methods of social scientists. There are two different paradigms to understand the character of social reality. These are the positivist approach and the post-positivist approach. In the positivist approach, social facts and events are defined objectively. According to the post-positivist approach, social events are formed by the effect of the social reality and the changing social relations (Bryman, 2016: 32). That is why it is also called the constructivist approach.

The paradigm adopted by the researcher in social sciences also includes methods on how to conduct a research in line with philosophical assumptions and principles (Neuman, 2014: 9). Positivism offers an epistemological approach that suggests that the methods used in natural sciences can also be used in social research (Güler et al., 2013: 19-20). Positivism is also called logical empiricism and the main purpose of this paradigm is to provide foresight by using experimental, quasi-experimental and causal comparison methods (Glesne, 2013: 9). Qualitative research describes a social event in its natural environment and natural formation (Ilgar and Coşgun Ilgar, 2013: 199).

Until the 1980s, the use of positivist paradigm continued by increasing its effect in the marketing field. Until these years, the general problem in marketing research has been the prediction and control of consumer behavior. In the marketing theory, although it is seen that 
many marketing concepts were taken from different disciplines such as sociology and anthropology after 1960s, these were included in the field of marketing in the context of positivist paradigm (Sağlam Arı et al., 2009: 124).

Watzlawick says that social reality has two aspects, the first order reality and the second order reality. First order reality expresses the objective, scientific and demonstrable side of reality. Second-order reality is created by attributing meaning to reality. According to Watzlawick, the reason for the current debate stems from the fact that people forget these two truths in their lives or do not know at all. Thus, people see the reality in social life as the only reality formed as a result of perceiving and making sense of the world. (Güler et al., 2013).

Qualitative and quantitative research methods have different assumptions. Both feature different methods and allow researchers to search for meaningful answers to their research questions in areas where these methods are appropriate (Yıldırım and Şimşek, 2016: 321). For example, the positivist approach is suitable for making predictions about consumer behavior. The post-positivist approach emphasizes the importance of understanding and interpreting consumer behavior. In today's societies, referred to as the consumption society, consumption is becoming more and more complex. Therefore, it is difficult to predict and model the consumer behavior. In such a situation, qualitative research can offer more effective tools than quantitative research in understanding and interpreting the theories used in the consumption process (Özhan Dedeoğlu, 2002: 75).

When it is desired to take a functional approach to research methods, which of the research problems can be solved with qualitative methods and which can be with quantitative methods should be carefully evaluated (Muijs, 2004: 6).

\section{Literature Review}

\subsection{Quantitative Research and Positivist Paradigm}

The purpose of logical positivists was to propose solutions to distinguish between scientific and non-scientific. Advocates of this trend have suggested that hypotheses or theories created by experience can only be converted into scientific knowledge by validating experiments and observations (Sınıksaran and Aktütün, 2004: 48). According to positivism, science is an effort to obtain predictive and explanatory information about the outside world. Positivism, methodologically, accepts the principle of "unity". According to this principle, there is only one science, and every intellectual activity named science must conform to this logic (Keat and Urry, 2016).

According to positivism, the scientific methods used when examining and explaining physical realities can also be used in social sciences. In quantitative research based on positivism, it is possible to make more objective analysis and inferences based on numerical values instead of subjective estimation of data obtained through observations and various techniques (Güler et al., 2013: 47).

When the basic beliefs of the positivist paradigm are evaluated, the position of positivism on ontologically is realism. The designed research is based on external realities that can be agreed upon. It is epistemologically objective, and the researcher tries to identify "how things really are" and "how they actually work". Positivism focuses on methodologically empirical methods and verification of hypotheses (Guba and Lincoln, 1994: 107-108).

Confirmed hypotheses that will be accepted as facts constitute the nature of positivist information. In the positivist paradigm, the quality of research depends on strict rules. Internal 
and external validity, reliability and objectivity are indispensable. A research dealt with positivist approach is isolated from values (Kuş, 2012).

Quantitative approach, with its simplest definition, is empirical research using data in numerical forms. However, the term quantitative research is much more than just research with numerical data. It means all ways of compiled or put together thought or approach (Punch, 2014: 3).

Different problems require different methods. Question expressions that include terms such as affecting factors, variable, determining factor, relationship are question statements that require working with the quantitative method (Punch, 2014: 23). If the problem is to identify the factors affecting the results, to make a useful intervention or to understand the best estimates of the results, quantitative research is the best method to use (Creswell, 2013: 20).

According to Muijs (2004), there are four main research cases in which quantitative methods should be used. The first of these is when numerical data are required. The second is when there are numerical changes. Thirdly, it can be used in situations where it is desired to explain a concept as well as revealing the situation of something or someone. Fourth, it is used when hypotheses need to be tested.

The strengths and weaknesses of quantitative research can be summarized as follow (Hughes, 2006).

The strengths

- Accuracy: Accuracy is achieved with quantitative and reliable measurements.

- Control: It means that the sample and design are suitable for control.

- Revealing causality: It is provided through the use of controlled experiments.

- Complex analysis can be made easily with statistical methods.

- Repeatability: It can be checked by other researchers.

The weaknesses

- Due to the complex nature of human behavior, it is difficult to control or eliminate all variables.

- Humans do not react in the same way as stationary substances subject to science.

- The mechanical moral structure of the quantitative method tends to exclude the notions of freedom, choice and moral responsibility.

The most common data collection techniques used in quantitative research are surveys and experiments. The questionnaire is prepared to be asked to the respondent and it is a list of questions with spaces for recording answers (Gegez, 2010: 191). Experiments are a technique often used in science and are more suited to the nature of science. The purpose of the experiments is to establish a cause and effect relationship (Geray, 2016: 79). 


\subsection{Qualitative Research and Post-positivist Paradigm}

The ontological position of post-positivism is idealism. According to this belief, the world cannot exist by isolating thoughts. According to the ontological belief of post-positivism, reality occurs in the social environment, is complex and constantly changes. Therefore, it is important how people interpret and make sense of certain objects, events, behaviors, perceptions. In terms of methodology, it includes interacting with individuals in a particular social context about their perception. For this, observations and interviews are made with the participants of the research. In the analysis stage, relationships are investigated (Glesne, 2013: 11).

According to the post-positivist paradigm, "there is no single and most correct form in obtaining information". Perspectives are more important than objectivity (Yıldırım and Şimşek, 2016: 31). Since it has been understood that qualitative research is more important than thought in recent years, it has been started to widely used. It is seen that it is cheaper and functional in revealing intrinsic motivations and emotions. Also it assists quantitative research. These are more encouraging factors for the use of qualitative research (Gegez, 2010: 47).

Qualitative research has strong theoretical foundations based on various disciplines. The common aim in psychology, philosophy, linguistics, sociology, anthropology and similar disciplines is to try to understand human behavior within the context and multi-dimensionally. According to these, traditional methods used in science are insufficient in understanding human behavior (Yıldırım and Şimşek, 2016: 37).

Question statements containing terms such as exploring, explaining experience, exploring the process are situations that require working with qualitative methods (Punch, 2014: 23). Detailed explanation of a complex subject is the aim of qualitative research. Another aim of qualitative research is to improve theories that are partially sufficient or insufficient (Creswell, 2013: 48).

Qualitative research has no definition accepted by everyone. It includes research designs such as ethnography, descriptive research, natural research, theory development, content analysis. Qualitative research can be defined as a general concept that includes these research designs (Tanyaş, 2014: 26; Yıldırım and Şimşek, 2016: 41).

In qualitative research, the issue of validity is controversial and can be seen as a weak aspect. However, many researchers believe that concepts are socially structured. So they believe that there can be no criterion to make sure the concepts are correct or precise. In qualitative research, the concept of credibility is used instead of validity. To provide credibility, solutions such as long-term interaction, continuous observation, use of multiple data collection techniques, contrast situation analysis, explanation of researcher biases, participant approval, providing rich descriptions and activating the external audit mechanism are produced (Glesne, 2013: 66). The approach where multiple data collection methods and techniques are used together is called triangulation. The purpose of collecting data from different data sources in qualitative research is to eliminate the risk of the researcher making systematic errors (Maxwell, 2012). Also, according to the qualitative research paradigm, social reality cannot be evaluated separately from the perception and comprehension processes of human beings, thus assumes that the researcher cannot be neutral in the research process (Özdemir, 2010: 326).

Research designs are strategies that determine the approach of the research and guide the consistency of the stages (Ilgar and Coşgun Ilgar, 2013: 201). Basic qualitative research designs are ethnographic studies, phenomenological studies, case studies, action research, grounded theory and narrative studies (Creswell, 2013; Glesne, 2013; Ilgar and Coşgun Ilgar, 2013). 
Ethnographic studies are the whole of scientific efforts to understand and describe a group of people or a group's culture (Kartar1, 2017: 217).

Phenomenology explores experiences itself and explain how the experience turns consciousness. Phenomenologists research the experiences (Merriam, 2013: 25).

Case studies are a type of study in which a single social unit is studied in detail (Payne and Payne, 2004: 31).

Action research is research that is used to identify and solve problems related to a group, community or organization or to understand a particular situation (Glesne, 2013: 32).

Acording to Denzin and Lincoln (2008: 561) grounded theory is a broad inductive method that develops theory by associate close relationships with the observational world.

As a method, the narrative consists of stories and experiences told by individuals. Enables understanding and analysing the experiences and stories told (Creswell, 2013: 70).

Table 1. Comparison of quantitative and qualitative research methods

\begin{tabular}{|c|c|}
\hline Quantitative Research & Qualitative Research \\
\hline \multicolumn{2}{|c|}{ Philosophical foundations } \\
\hline $\begin{array}{l}\text { Positivism. } \\
\text { Logical Empiricism } \\
\text { Realism }\end{array}$ & $\begin{array}{l}\text { Post-positivism. } \\
\text { Symbolic interactionism. } \\
\text { Phenomenology. }\end{array}$ \\
\hline \multicolumn{2}{|c|}{ Focus of research } \\
\hline Quantity (how many, how much ...) & Quality (essence) \\
\hline \multicolumn{2}{|c|}{ Assumptions } \\
\hline $\begin{array}{l}\text { Reality is objective. } \\
\text { The main thing is the method. } \\
\text { Variables can be determined with strict limits. } \\
\text { Relationships between variables can be measured. } \\
\text { The researcher is objective. }\end{array}$ & $\begin{array}{l}\text { Reality is created. } \\
\text { The main thing is the situation studied. } \\
\text { Variables are complex and intertwined. } \\
\text { It is difficult to measure the relationship between variables. } \\
\text { The researcher is a participatory. }\end{array}$ \\
\hline \multicolumn{2}{|r|}{ Purpose } \\
\hline $\begin{array}{l}\text { Generalization. } \\
\text { Estimating. } \\
\text { Understanding causality. }\end{array}$ & $\begin{array}{l}\text { Description. } \\
\text { Interpretation. } \\
\text { Comprehending perspectives. }\end{array}$ \\
\hline \multicolumn{2}{|c|}{ Approach } \\
\hline $\begin{array}{l}\text { It starts with theory and hypothesis. } \\
\text { Experiment, manipulation and control are involved in the } \\
\text { process. } \\
\text { Standardized data collection tools are used. } \\
\text { Parts are analyzed. } \\
\text { There is a search for reconciliation and norm. } \\
\text { The data are reduced to numerical indicators. } \\
\text { There is a deductive understanding }\end{array}$ & $\begin{array}{l}\text { It ends with theory and assumption. } \\
\text { It has a natural structure in its entirety. } \\
\text { The researcher is also included as a data collection tool. } \\
\text { Relations are tried to be revealed. } \\
\text { Pluralism and differences are sought. } \\
\text { The data are depicted in depth. } \\
\text { There is an inductive understanding. } \\
\text { It is done in a natural environment. } \\
\text { The reports are written in great detail. }\end{array}$ \\
\hline \multicolumn{2}{|c|}{ The role of researcher } \\
\hline $\begin{array}{l}\text { The researcher is out of the events. } \\
\text { Acts neutral and objectively. }\end{array}$ & $\begin{array}{l}\text { The researcher gets involved in the events. } \\
\text { The researcher's individual interest is in question. } \\
\text { The researcher approaches with a subjective perspective and } \\
\text { empathy. }\end{array}$ \\
\hline
\end{tabular}

Source: (Glesne, 2013: 12; Merriam, 2013; Yıldırım and Şimşek, 2016: 49).

\section{Method}

Nowadays, as a result of the presence of many fashion insights such as fast fashion, slow fashion, luxury fashion, the reactions of consumers have differentiated and studies in fashion marketing have increased by diversifying. However, all studies done about fashion marketing are designed to solve different and unique problems. The definition of the problem and the research paradigm cannot be considered separately, and each problem requires a unique 
methodology. This study is designed to understand this difference and create a framework for the method in fashion marketing studies.

The aim of this study is to describe the fashion marketing studies by evaluating the method issue in the social sciences within the framework of the positivist and post-positivist paradigm. Within the scope of the study, master's and doctoral theses in the field of Fashion Marketing in CoHE National Thesis Center were examined in terms of method. By examining the history and the change of fashion marketing studies in terms of method, existing traditional approaches have been describe and a framework has been established for what the new approaches are.

This study is a quantitative research based on document analysis. Within the scope of the study, master's and doctoral theses published in the field of Fashion marketing from 1986 to 2019 were examined. The paradigm on which the theses are about, the methodological approach used, data collection tools, data analysis methods and research patterns that reveal the purpose of the study were examined.

In the research, there is not any sampling process and all units were examined. A total of 154 theses, including 25 doctorates and 129 masters, were examined within the scope of the study. The distribution of the studies by years are presented with cross tables, and chi square and single sample $t$ test analyzes were also used.

\section{Research Findings}

When the data are analyzed regardless of the paradigm, it can be seen that the theses studied in the field of fashion marketing have increased over the years. The first thesis in this field was studied in 1986. As can be seen in Figure 1, no master or doctoral thesis written in this field was found in 1987, 1988, 1991, 1992 and 2001.

"One Sample T-Test" analysis was done to examine whether this change was statistically significant over the years. According to Table 2, there are statistically significant differences according to thesis distribution in the years they were published.

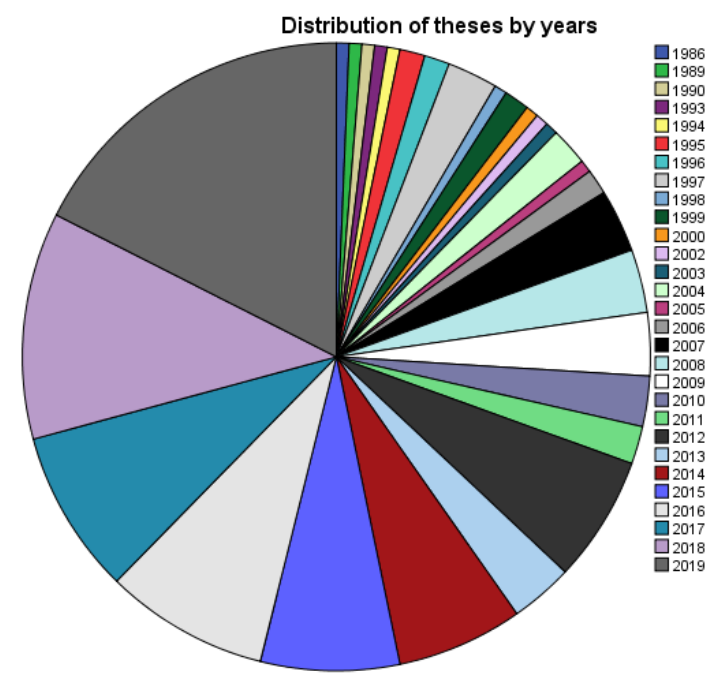

Figure 1. Distribution of theses on fashion marketing by years 
Table 2. T-test results

\begin{tabular}{lcccc}
\hline & T & Df & Sig. (2-tailed) & Mean Difference \\
\hline $\begin{array}{l}\text { Publication year of the } \\
\text { Theses }\end{array}$ & 3347.173 & 153 & .000 & 2007.070 \\
\hline
\end{tabular}

After this process, master's and doctoral theses are presented separately in Table 3 in terms of research approach. In addition, all theses in total are shown in Table 3. Whether the theses are significantly different in terms of approach by years was examined by chi-square analysis.

According to the results of the analysis, there has been an increase in the adoption of a qualitative research approach, but it is seen the widespread paradigm is quantitative research. As stated in Table 3, the rate of quantitative studies in total is $68.8 \%$, while qualitative studies are $27.3 \%$, and mixed studies are $3.9 \%$.

Since 1996, researchers have started to use qualitative researches in fashion marketing master theses. In the doctoral theses, the first qualitative study was written in 1998, but there were no other studies published until 2012. In addition to these, mixed patterns, in which quantitative research and qualitative research are used together, have been started to use especially in the last few years.

It was also investigated whether all theses were statistically significant by years in terms of the paradigm. For this purpose, Chi-square analysis was done. Consequently, since the $p$ value is greater than 0.05 , it cannot be said that the distribution of published theses over the years differs statistically in terms of the paradigm. Chi-square analysis was applied to master and doctoral theses separately and a statistical significance was not observed here also.

When the total analysed, there is an increase in qualitative and mixed studies since 2014. Accordingly, although there are 48 studies in total, qualitative and mixed studies, 31 of them are studies between 2014-2019. While the ratio of the studies in which qualitative and mixed approach was adopted in the first 28 years, the ratio in the total was $35.5 \%$, only in the last 6 years this ratio has been $65.5 \%$. This shows that although the dominant paradigm is positivist approach and quantitative studies are still used frequently, qualitative and mixed approaches have also begun to adopt. 
Table 3. Distribution of theses on fashion marketing by years and paradigms

\begin{tabular}{|c|c|c|c|c|c|c|c|c|c|c|c|c|}
\hline \multirow{2}{*}{ Year } & \multicolumn{4}{|c|}{ Master Theses } & \multicolumn{4}{|c|}{ Doctoral Theses } & \multicolumn{3}{|c|}{ All Theses } & \multirow[b]{2}{*}{ Total } \\
\hline & Quan. & Qual. & Mix. & $\mathrm{N}$ & Quan. & Qual. & Mix. & $\mathrm{N}$ & Quan. & Qual. & Mix. & \\
\hline 1986 & 1 & & & 1 & & & & & 1 & & & 1 \\
\hline 1989 & 1 & & & 1 & & & & & 1 & & & 1 \\
\hline 1990 & & & & & 1 & & & 1 & 1 & & & 1 \\
\hline 1993 & 1 & & & 1 & & & & & 1 & & & 1 \\
\hline 1994 & 1 & & & 1 & & & & & 1 & & & 1 \\
\hline 1995 & 1 & & & 1 & 1 & & & 1 & 2 & & & 2 \\
\hline 1996 & & 2 & & 2 & & & & & & 2 & & 2 \\
\hline 1997 & 2 & 2 & & 4 & & & & & 2 & 2 & & 4 \\
\hline 1998 & & & & 0 & & 1 & & 1 & & 1 & & 1 \\
\hline 1999 & 1 & 1 & & 2 & & & & & 1 & 1 & & 2 \\
\hline 2000 & & 1 & & 1 & & & & & & 1 & & 1 \\
\hline 2002 & & 1 & & 1 & & & & & & 1 & & 1 \\
\hline 2003 & 1 & & & 1 & & & & & 1 & & & 1 \\
\hline 2004 & 2 & & & 2 & 1 & & & 1 & 3 & & & 3 \\
\hline 2005 & 1 & & & 1 & & & & & 1 & & & 1 \\
\hline 2006 & & 1 & & 1 & 1 & & & 1 & 1 & 1 & & 2 \\
\hline 2007 & 3 & 2 & & 5 & & & & & 3 & 2 & & 5 \\
\hline 2008 & 3 & 1 & & 4 & 1 & & & 1 & 4 & 1 & & 5 \\
\hline 2009 & 1 & 1 & 1 & 3 & 2 & & & 2 & 3 & 1 & 1 & 5 \\
\hline 2010 & 3 & 1 & & 4 & & & & & 3 & 1 & & 4 \\
\hline 2011 & 2 & & & 2 & 1 & & & 1 & 3 & & & 3 \\
\hline 2012 & 8 & 1 & & 9 & & 1 & & 1 & 8 & 2 & & 10 \\
\hline 2013 & 3 & & & 3 & 2 & & & 2 & 5 & & & 5 \\
\hline 2014 & 4 & 3 & & 7 & 2 & 1 & & 3 & 6 & 4 & & 10 \\
\hline 2015 & 6 & 2 & & 8 & 2 & & 1 & 3 & 8 & 2 & 1 & 11 \\
\hline 2016 & 8 & 2 & & 10 & 1 & 1 & 1 & 3 & 9 & 3 & 1 & 13 \\
\hline 2017 & 5 & 6 & & 11 & 1 & 1 & & 2 & 6 & 7 & & 13 \\
\hline 2018 & 12 & 4 & 1 & 17 & 1 & & & 1 & 13 & 4 & 1 & 18 \\
\hline 2019 & 18 & 6 & 2 & 26 & 1 & & & 1 & 19 & 6 & 2 & 27 \\
\hline Total & $\begin{array}{c}88 \\
\% 68.2\end{array}$ & $\begin{array}{c}37 \\
\% 28.7\end{array}$ & $\begin{array}{c}4 \\
\% 3.1\end{array}$ & $\begin{array}{c}129 \\
\% 100\end{array}$ & $\begin{array}{c}18 \\
\% 72\end{array}$ & $\begin{array}{c}5 \\
\% 20\end{array}$ & $\begin{array}{c}2 \\
\% 8\end{array}$ & $\begin{array}{c}25 \\
\% 100\end{array}$ & $\begin{array}{c}106 \\
\% 68.8\end{array}$ & $\begin{array}{c}42 \\
\% 27.3\end{array}$ & $\begin{array}{c}6 \\
\% 3.9\end{array}$ & $\begin{array}{c}154 \\
\% 100\end{array}$ \\
\hline
\end{tabular}

Table 4 shows the data collection tool, analysis type and research designs of quantitative theses. In quantitative research, questionnaires are frequently used as a data collection tool in both master $(98.9 \%)$ and doctorate $(100 \%)$ thesis. In positivist research, how the data is collected depends on the character of the research design. In cases where data will be collected from people, surveys are one of the tools that can be used for this purpose. In social sciences, surveys are used as the data collection method in most quantitative research. With the help of the survey, data can be collected by face-to-face communication, e-mail, phone call or computer (Erdoğan, 2012: 214-216).

In addition to the surveys, there are also master thesis conducted with secondary data as an exception $(1,1 \%)$. Secondary data are data previously collected for other research. Such data can be provided from within the enterprise, from libraries or from various government institution. Information in books and articles and information on websites are also considered as secondary data (Gegez, 2010: 67).

As data analysis type, it is seen that statistical analysis is widely used in both master $(100 \%)$ and doctorate $(100 \%)$ thesis. The type of statistical analysis varies according to the research purpose of the study. Descriptive statistics such as frequency and percentage distributions were used in descriptive studies. In causal studies, T-test, ANOVA, Chi-square test, Factor analysis, Regression analysis, Correlation analysis and similar analysis techniques were used to calculate the coefficients showing the direction and effect of the relationship between variables and to test hypothesis. 
As a research design, causal approach has been used at 79.5\% in master theses and $94.4 \%$ in doctoral theses. Descriptive approach was used at $20.5 \%$ in master theses and $5.6 \%$ in doctoral theses. Descriptive studies try to explain what a particular situation is. The purpose of these studies is to describe or clarify a situation, people, relationship, organized activity or communication process. Descriptive studies are concerned with the qualities of phenomena. (Erdoğan, 2007: 138) and try to define the characteristics of a particular group such as age, education level, profession. These studies try to answer the questions, such as who, what, when, where and how ect. The purpose of causal research is to determine the cause and effect relationships between the variables. In these studies, it is determined whether there is a relationship between the variables (Gegez, 2010: 38).

Table 4. Quantitative theses on fashion marketing

\begin{tabular}{|c|c|c|c|c|c|c|c|c|c|}
\hline \multirow{3}{*}{ Year } & \multicolumn{5}{|c|}{ Master Theses } & \multicolumn{4}{|c|}{ Doctoral theses } \\
\hline & \multicolumn{2}{|c|}{ Data collection tool } & \multirow{2}{*}{$\begin{array}{c}\begin{array}{c}\text { Analysis } \\
\text { type }\end{array} \\
\text { Statistical } \\
\underline{\text { analysis }} \\
\end{array}$} & \multicolumn{2}{|c|}{ Research designs } & \multirow{2}{*}{$\begin{array}{c}\begin{array}{c}\text { Data } \\
\text { collec } \\
\text { tion } \\
\text { tool }\end{array} \\
\frac{\text { Surve }}{y} \\
\end{array}$} & \multirow{2}{*}{$\begin{array}{c}\begin{array}{c}\text { Analysis } \\
\text { type }\end{array} \\
\text { Statistical } \\
\text { analysis }\end{array}$} & \multicolumn{2}{|c|}{ Research designs } \\
\hline & $\underline{\text { Survey }}$ & $\underline{\text { Sec. }}$ & & $\underline{\text { Desc. }}$ & $\frac{\text { Causa }}{1}$ & & & $\underline{\text { Desc. }}$ & $\underline{\text { Causal }}$ \\
\hline 1986 & 1 & & 1 & 1 & & & & & \\
\hline 1989 & 1 & & 1 & & 1 & & & & \\
\hline 1990 & & & & & & 1 & 1 & & 1 \\
\hline 1993 & 1 & & 1 & & 1 & & & & \\
\hline 1994 & 1 & & 1 & & 1 & & & & \\
\hline 1995 & 1 & & 1 & 1 & & 1 & 1 & 1 & \\
\hline 1997 & 2 & & 2 & 2 & & & & & \\
\hline 1999 & 1 & & 1 & & 1 & & & & \\
\hline 2003 & 1 & & 1 & 1 & & & & & \\
\hline 2004 & 2 & & 2 & & 2 & 1 & 1 & & 1 \\
\hline 2005 & 1 & & 1 & 1 & & & & & \\
\hline 2006 & & & & & & 1 & 1 & & 1 \\
\hline 2007 & 3 & & 3 & 1 & 2 & & & & \\
\hline 2008 & 3 & & 3 & 1 & 2 & 1 & 1 & & 1 \\
\hline 2009 & 1 & & 1 & 1 & & 2 & 2 & & 2 \\
\hline 2010 & 3 & & 3 & & 3 & & & & \\
\hline 2011 & 2 & & 2 & & 2 & 1 & 1 & & 1 \\
\hline 2012 & 8 & & 8 & 1 & 7 & & & & \\
\hline 2013 & 3 & & 3 & & 3 & 2 & 2 & & 2 \\
\hline 2014 & 4 & & 4 & 1 & 3 & 2 & 2 & & 2 \\
\hline 2015 & 6 & & 5 & 1 & 5 & 2 & 2 & & 2 \\
\hline 2016 & 8 & & 8 & 2 & 6 & 1 & 1 & & 1 \\
\hline 2017 & 5 & & 5 & & 5 & 1 & 1 & & 1 \\
\hline 2018 & 11 & 1 & 12 & 3 & 96 & 1 & 1 & & 1 \\
\hline 2019 & 18 & & 19 & 1 & 17 & 1 & 1 & & 1 \\
\hline \multirow{2}{*}{ Total } & 87 & 1 & 88 & 18 & 70 & 18 & 18 & 1 & 17 \\
\hline & $\% 98.9$ & $\% 1.1$ & $\% 100$ & $\% 20.5$ & $\% 79.5$ & $\% 100$ & $\% 100$ & $\% 5.6$ & $\% 94.4$ \\
\hline
\end{tabular}

Table 5 shows the data collection tool, analysis type and research designs of qualitative master theses.

How the data is obtained in qualitative research varies according to the character of the source and the research (Erdoğan, 2012: 214). It is remarkable that secondary data (56.8\%) and in-depth interviews (27\%) are frequently used in qualitative master theses. Secondary data are obtained through document reviews. Document review is the analysis of written materials that contain information about the phenomenon or facts about research subject. It is often used in conjunction with other data collection methods. However, it can also be used as a data collection method in itself (Yıldırım and Şimşek, 2016: 189). In-depth interviews are detailed interviews 
done with individuals on a specific subject. (Gegez, 2010: 53). In addition, focus group interviews, another interview technique, were also conducted in theses $(8,1 \%)$. As a qualitative method of data collection, focus group interviews are interviews done with people who have knowledge about a particular subject (Merriam, 2013: 91). There are also theses studied with more than one data collection tool $(8,1 \%)$. This is one of the ways to find solutions to the problem of validity in qualitative studies. This method, known as triangulation, can be defined as the collection of additional proof from different sources to clarify a theme or perspective. Thus, it can be said that the findings are valid (Creswell, 2013: 301).

Qualitative researches are not designed to be linear and step by step. In such studies, data analysis and data collection are put into practice simultaneously (Merriam, 2013: 157). The most commonly used data analysis technique in qualitative master theses is document analysis with the rate $37,8 \%$. Those follow the document analysis in terms of frequency are descriptive analysis $(27 \%)$ and content analysis $(21,6 \%)$. Semiology analysis $(8,1 \%)$ and thematic analysis $(2,7 \%)$ are also have been used in master's theses. There are also studies conducted with multiple methods $(2,7 \%)$.

Document analysis means the analysis of written materials that contain information about the subjects of the research (Y1ldırım and Şimşek, 2016: 189).

The purpose of the descriptive analysis is to present the findings to the reader in a regular and interpreted manner. It is used in studies where the conceptual structure is clearly determined. In the content analysis, the data collected are analyzed in depth and it is tried to reveal the previously unknown themes and dimensions. In content analysis, it is aimed to explore the concepts that can explain the data (Yıldırım and Şimşek, 2016: 239).

Semiotic analysis focuses on determining how signs occur or what they mean in certain contexts. The system, integrated with signs, produces a social code. Dynamics and indirect meanings beyond superficial meanings are tried to be revealed (Glesne, 2013: 258).

In thematic analysis, the data are encoded and used for later descriptions and analysis. In thematic analysis, the researcher uses analytical techniques to find patterns and themes by using data (Glesne, 2013: 259).

Descriptive and exploratory researches were frequently used as research designs in qualitative master theses. Studies where both designs are used together are also named as mixed patterns.

The most common used research design in qualitative master theses is descriptive research $(67,6 \%)$. Exploratory studies are the second most frequently used research pattern after descriptive studies in master's theses with $29,7 \%$. In exploratory studies, it is aimed to reveal a problem and its dimensions. It is used in cases where previous studies are limited. (Gegez, 2010: 34). The rate of studies designed with mixed patterns in master theses is $2,7 \%$. 
Table 5. Qualitative master theses on fashion marketing

\begin{tabular}{|c|c|c|c|c|c|c|c|c|c|c|c|c|c|}
\hline \multirow[b]{2}{*}{ Year } & \multicolumn{4}{|c|}{ Data collection tool } & \multicolumn{6}{|c|}{ Analysis type } & \multicolumn{3}{|c|}{ Research designs } \\
\hline & $\frac{\text { Focus }}{\text { group }}$ & $\begin{array}{l}\frac{\text { In- }}{\text { depth }} \\
\frac{\text { Int. }}{\text { nt }}\end{array}$ & $\frac{\underline{\text { Sec. }}}{\underline{\text { Data }}}$ & $\underline{\text { Multi. }}$ & $\frac{\text { Desc. }}{\underline{\text { An }}}$ & $\frac{\text { Doc. }}{\underline{\text { an. }}}$ & $\frac{\text { Cont. }}{\underline{\text { an. }}}$ & $\frac{\text { Semiotic }}{\underline{\text { an. }}}$ & $\frac{\text { Thema. }}{\underline{\text { an. }}}$ & $\underline{\text { Multi. }}$ & Desc. & Exp. & $\underline{\text { Mix. }}$ \\
\hline 1996 & & & 2 & & & 2 & & & & & 2 & & \\
\hline 1997 & & & 2 & & & 1 & & 1 & & & 2 & & \\
\hline 1999 & & & 1 & & & 1 & & & & & 1 & & \\
\hline 2000 & & 1 & & & 1 & & & & & & & 1 & \\
\hline 2002 & & & 1 & & & 1 & & & & & 1 & & \\
\hline 2006 & & & 1 & & & 1 & & & & & 1 & & \\
\hline 2007 & & & 2 & & & 2 & & & & & 2 & & \\
\hline 2008 & & & 1 & & & 1 & & & & & 1 & & \\
\hline 2009 & & & & 1 & & & & & & 1 & & & 1 \\
\hline 2010 & & 1 & & & & & 1 & & & & 1 & & \\
\hline 2012 & & 1 & & & 1 & & & & & & 1 & & \\
\hline 2014 & & & 2 & 1 & 1 & 2 & & & & & 3 & & \\
\hline 2015 & & 1 & 1 & & & 1 & & & 1 & & 1 & 1 & \\
\hline 2016 & 1 & 1 & & & 1 & & 1 & & & & 1 & 1 & \\
\hline 2017 & 1 & 3 & 2 & & 4 & & 1 & 1 & & & 2 & 4 & \\
\hline 2018 & & 1 & 3 & & 1 & 1 & 2 & & & & 3 & 1 & \\
\hline 2019 & 1 & 1 & 3 & 1 & 1 & 1 & 3 & 1 & & & 3 & 3 & \\
\hline & 3 & 10 & 21 & 3 & 10 & 14 & 8 & 3 & 1 & 1 & 25 & 11 & 1 \\
\hline Total & $\% 8.1$ & $\% 27$ & $\% 56.8$ & $\% 8.1$ & $\% 27$ & $\% 37.8$ & $\% 21.6$ & $\% 8.1$ & $\% 2.7$ & $\% 2.7$ & $\% 67.6$ & \%29.7 & $\% 2.7$ \\
\hline
\end{tabular}

6 shows the data collection tool, analysis type and research designs of qualitative doctoral theses.

According to the table, in the qualitative doctoral theses, secondary data were used as the data collection tool with a rate of $57.1 \%$. The rate of data collection with multiple methods is $28.6 \%$ and the rate of focus group interview is $14.3 \%$.

In doctoral theses, semiology analysis (28.6\%) and multiple analysis methods $(28.6 \%)$ were used more than others. And exploratory studies (42.9\%) were used more than descriptive $(28.6 \%)$ and mixed studies $(28.6 \%)$.

Table 6. Qualitative doctoral theses on fashion marketing

\begin{tabular}{|c|c|c|c|c|c|c|c|c|c|c|c|}
\hline \multirow[b]{2}{*}{ Year } & \multicolumn{3}{|c|}{ Data collection tool } & \multicolumn{5}{|c|}{ Analysis type } & \multicolumn{3}{|c|}{ Research designs } \\
\hline & $\frac{\text { Focus }}{\text { group }}$ & $\frac{\text { Sec. }}{\text { Data }}$ & Multi. & $\frac{\text { Desc. }}{\text { an. }}$ & $\frac{\text { Doc. }}{\text { An. }}$ & $\frac{\text { Semiotic }}{\text { an. }}$ & $\frac{\text { Thematic }}{\text { an. }}$ & Multi. & Desc. & Exp. & $\underline{\text { Mix. }}$ \\
\hline 1998 & & 1 & & & 1 & & & & 1 & & \\
\hline 2012 & & 1 & & 1 & & & & & 1 & & \\
\hline 2014 & & 1 & & & & 1 & & & & 1 & \\
\hline 2015 & 1 & & & & & & & 1 & & & 1 \\
\hline 2016 & & & 2 & & & & 1 & 1 & & 1 & 1 \\
\hline 2017 & & 1 & & & & 1 & & & & 1 & \\
\hline Total & $\begin{array}{c}1 \\
\% 14.3\end{array}$ & $\begin{array}{c}4 \\
\% 57.1\end{array}$ & $\begin{array}{c}2 \\
\% 28.6\end{array}$ & $\begin{array}{c}1 \\
\% 14.3\end{array}$ & $\begin{array}{c}1 \\
\% 14.3\end{array}$ & $\begin{array}{c}2 \\
\% 28.6\end{array}$ & $\begin{array}{c}1 \\
\% 14.3\end{array}$ & $\begin{array}{c}2 \\
\% 28.6\end{array}$ & $\begin{array}{c}2 \\
\% 28.6\end{array}$ & $\begin{array}{c}3 \\
\% 42.9\end{array}$ & $\begin{array}{c}2 \\
\% 28.6\end{array}$ \\
\hline
\end{tabular}

Table 7 shows the data collection tool, analysis type and research designs of mixed design theses.

Qualitative research also can be seen as a complement to quantitative research. In some cases, qualitative research is followed by quantitative research (Gegez, 2010: 47). Such situations are called mixed methods in which qualitative research and quantitative research are used together. These studies are based on pragmatist philosophy (Yıldırım and Şimşek, 2016: $322)$. 
In master and doctoral theses, it is seen that multiple data collection tools and multiple analysis types are used frequently in accordance with the character of mixed studies. And mixed designs are frequently used as a research design.

Table 7. Mixed theses on fashion marketing

\begin{tabular}{|c|c|c|c|c|c|c|c|c|c|c|c|c|}
\hline \multirow{3}{*}{ Year } & \multicolumn{6}{|c|}{ Master theses } & \multicolumn{6}{|c|}{ Doctoral theses } \\
\hline & \multicolumn{2}{|c|}{$\begin{array}{c}\text { Data collection } \\
\text { tool }\end{array}$} & \multicolumn{2}{|c|}{ Analysis type } & \multicolumn{2}{|c|}{$\begin{array}{l}\text { Research } \\
\text { designs }\end{array}$} & \multicolumn{2}{|c|}{$\begin{array}{c}\text { Data collection } \\
\text { tool }\end{array}$} & \multicolumn{2}{|c|}{ Analysis type } & \multicolumn{2}{|c|}{$\begin{array}{c}\text { Research } \\
\text { designs }\end{array}$} \\
\hline & $\frac{\underline{\text { In- }}}{\frac{\text { depth }}{\text { int. }}}$ & $\underline{\text { Sec. }}$ & Multi. & $\frac{\text { Desc. }}{\underline{\text { an. }}}$ & Multi. & Desc. & Exp. & Mix. & $\frac{\text { Focus }}{\text { group }}$ & Multi. & Multi. & $\underline{\text { Mix. }}$. \\
\hline 2009 & & & 1 & & 1 & 1 & & & & & & \\
\hline 2015 & & & & & & & & & 1 & & 1 & 1 \\
\hline 2016 & & & & & & & & & & 1 & 1 & 1 \\
\hline 2018 & & 1 & & & 1 & & & 1 & & & & \\
\hline 2019 & 1 & & 1 & 1 & 1 & 1 & 1 & & & & & \\
\hline Total & $\begin{array}{c}1 \\
\% 25\end{array}$ & $\begin{array}{c}1 \\
\% 25\end{array}$ & $\begin{array}{c}2 \\
\% 50\end{array}$ & $\begin{array}{c}1 \\
\% 25\end{array}$ & $\begin{array}{c}3 \\
\% 75\end{array}$ & $\begin{array}{c}2 \\
\% 50\end{array}$ & $\begin{array}{c}1 \\
\% 25\end{array}$ & $\begin{array}{c}1 \\
\% 25\end{array}$ & $\begin{array}{c}1 \\
\% 50\end{array}$ & $\begin{array}{c}1 \\
\% 50\end{array}$ & $\begin{array}{c}2 \\
\% 100\end{array}$ & $\begin{array}{c}2 \\
\% 100\end{array}$ \\
\hline
\end{tabular}

\section{Results}

Modern science has been dominated by the positivist paradigm for many years since its inception. Although the roots of insight, which is an alternative to the positivist paradigm, go back to old times, their effects on their methodological approach remained limited (Kuş, 2007: 20). The continuing trend in the field of research methods in the social sciences is positivist, and the use of complex mathematics / statistics is seen as an indicator of expertise in the subject. The ability to use these tools has become a norm and purpose (Özhan Dedeoğlu, 2002: 76).

According to the results of the study, it is seen that quantitative methods based on the positivist paradigm are also frequently used in fashion marketing studies. As Keat and Urry stated (2016), the principle of methodological "unity" in science also appear in quantitative studies in fashion marketing. In parallel with this understanding, there are not many different methods in terms of data collection and data analysis in quantitative theses. The use of questionnaires as a data collection tool and the use of statistical methods as a type of data analysis have almost become a norm and have been used frequently in studies in quantitative theses. When also past studies in the field of marketing are examined, it is seen that quantitative methods are widely used (Bakır, 2013; Sağlam Arı et al., 2009).

However, the tradition of testing hypotheses does not promote the emergence of new theories and facts. Quantitative studies ignore subprocesses in statistical relationships between variables, reduce inter-individual differences to group averages. The data collection process is very limited and the researcher must be objective. These are criticisms to quantitative studies (Tanyaş, 2014: 26). While objectivity is possible in the natural sciences, it is quite difficult to be objective in the social sciences because it is both the subject researched and the researcher are human. (Erdoğan, 2018: 17).

The widespread use of qualitative research method shows that there is an important change in social sciences in the 20th century. In the beginning of the century, quantitative approach began to crack. Because the researchers who adopted this approach were trying to measure and test the subject and the object without understanding the nature of the them. At the end of the century, it has started to be realized that the quantitative research method is not the most ideal method in itself (Kartar1, 2017: 209). Differences are important in social sciences and each structure within affects each other. Because in social sciences, there are many 
structures such as economics, psychology, law, philosophy, sociology, and marketing that influence each other's (Erdoğan, 2018). Due to these awareness, it has been revealed that qualitative research is important. So it has been started to be used intensively in recent years (Gegez, 2010: 47). As a result of the method criticism in social sciences, there has been a paradigm shift from positivism to post-positivism (Sağlam Arı et al., 2009: 122).

Acording to results of this study, while quantitative research is dominant paradigm in fashion marketing, it is an undeniable fact that the use qualitative and mixed research has increased in recent years. Different studies have also shown that there has been an increased interest in qualitative research over time (Sağlam Arı et al., 2009; Bakır, 2013).

In qualitative research, it is not possible to say that data collection tools and data analysis types have become the norm as in quantitative research. Different techniques can be used depending on the characteristics of the study. Data collection techniques frequently used in qualitative research are observations, interviews, and secondary data. The analysis techniques used are document analysis, content analysis, indicator analysis, descriptive analysis, thematic analysis.

It is known that both types of methods have strengths and weaknesses. Based on this assumption, mixed methods in which both methods are used as complementary for each others are started to be used. This type of research, called mixed design, has been used for the first time in 2009 both master's and doctoral theses, but its importance has increased gradually and its usage has increased in recent years. With mixed design research, a researcher can do multistrategy researches for a purpose such as "diversity of opinion" (Bryman, 2006: 110).

Qualitative research methods are often criticized by quantitative researchers and positivists. Nevertheless, these methods are frequently used in the field of social sciences to fill in the gaps, make in-depth meanings, define processes, reveal the main reasons behind the events. Based on the results of the study, researchers working in the social sciences are advised not to be limited in terms of methodologically while solving current problem. Researchers should make decisions considering alternative approaches and design the research in accordance with the character of the problem.

\section{References}

Bakır, N. O. (2013). Pazarlama alanında yapılan doktora tezlerinin kategorik olarak değerlendirilmesi (1994 - 2012). Journal of Marmara University Social Sciences Institute/Öneri, 10 (40), 1-13

Barnes , L., and Lea-Greenwood, G. (2006). "Fast fashioning the supply chain: shaping the research agenda. Journal of Fashion Marketing and Management, 10 (3), 259-271.

Bryman, A. (2006). Integrating quantitative and qualitative research: how is it done? Qualitative research, 6(1), 97-113.

Bryman, A. (2016). Social research methods (4th ed.). New York: Oxford University Press.

Creswell, J. W. (2013). Nitel araştırma yöntemleri, beş yaklaşıma göre nitel araştırma ve araştırma deseni. (M. Bütün, and S. B. Demir, Trans.) Ankara: Siyasal Kitabevi.

Denzin, N. K., and Lincoln, Y. S. (2008). The landscape of qualitative research (3rd ed.). Sage. Erdoğan, B. Z., Doğan, S. (2018). Sosyal Bilim Olarak Pazarlama. Bilim olarak pazarlama. İstanbul: Beta.

Erdoğan, İ. (2007). Pozitivist metodoloji: bilimsel araştırma tasarımı ve istatistiksel yöntemler analiz ve yorum (2nd ed.). Ankara: Erk Yayıncilık.

Erdoğan, İ. (2012). Pozitivist metodoloji ve ötesi araştırma tasarımları niteliksel ve istatistiksel yöntemler (3rd ed.). Ankara: Erk Yayınları. 
Gegez, E. (2010). Pazarlama araştırmaları (3rd ed.). İstanbul: Beta.

Geray, H. (2016). Toplumsal araştırmalarda nicel ve nitel yöntemlere giriş (2nd ed.). Ankara: Siyasal Kitabevi.

Glesne, C. (2013). Nitel araştırmaya giriş (2nd ed.). (A. Ersoy, and P. Yalçınoğlu, Trans.) Ankara: Anı Yayıncilik.

Guba, E. G., and Lincoln, Y. S. (1994). Competing paradigms in qualitative research. Los Angeles: Sage.

Güler, A., Halıcıoğlu, M. B., and Taşğın, S. (2013). Sosyal bilimlerde nitel araştırma. Ankara: Seçkin.

Güven, S. (1996). Toplum biliminde araştırma yöntemleri. Bursa: Ezgi Kitabevi.

Hughes, C. (2006). Quantitative and qualitative approaches to social research.

Ilgar, M. Z., and Coşgun Ilgar, S. (2013). Nitel bir araştırma deseni olarak gömülü teori. 197247.

Kaptan, S. (1995). Bilimsel araştırma ve istatistik teknikleri. Ankara: Tekış1k.

Kartarı, A. (2017). Nitel düşünce ve etnografi: etnografik yönteme düşünsel bir yaklaşım. Hacettepe Üniversitesi İletişim Fakültesi Kültürel Çalışmalar Dergisi, 4(1), 207-2020.

Keat, R., and Urry, J. (2016). Bilim olarak sosyal teori (3rd ed.). Ankara: İmge Kitabevi.

Kuş, E. (2012). Nicel-nitel araştırma teknikleri. Ankara: Anı Yayıncılık.

Kuş, E. (2007). Sosyal bilim metodolojisinde paradigma dönüşümü. Türk Psikoloji Yazıları, 10(20), 19-41.

Maxwell, J. A. (2012). Qualitative research design: an interactive approach (3rd ed). California: Sage.

Merriam, S. B. (2013). Nitel araştırma desen ve uygulama için bir rehber (3rd ed.). (S. Turan, Trans.) Ankara: Nobel Yayınc1lık.

Muijs, D. (2004). Introduction to quantitative research: doing quantitative research in education with SPSS.

Neuman, W. L. (2014). Social research methods qualitative and quantitative (7th ed.). Pearson.

Özdemir, M. (2010). Nitel veri analizi: Sosyal bilimlerde yöntembilim sorunsalı üzerine bir çalışma. Eskişehir Osmangazi Üniversitesi Sosyal Bilimler Dergisi, 11(1), 323-343.

Özhan Dedeoğlu, A. (2002). Tüketici davranışları alanında kalitatif araştırmaların önemi ve multidisipliner yaklaşımlar. Dokuz Eylül Üniversitesi İktisadi ve İdari Bilimler Fakültesi Dergisi, 17(2), 75-92.

Payne, G., and Payne, J. (2004). Key concepts in social research. Sage.

Punch, K. F. (2014). Social research quantitative qualitative approaches (3rd ed.). Sage.

Sağlam Arı, G., Armutlu, C., Güneri Tosunoğlu, N., and Yücel Toy, B. (2009). Pozitivist ve postpozitivist paradigmalar çerçevesinde metodoloji tartışmalarının yönetim ve pazarlama alanlarına yansımaları. Hacettepe Üniversitesi İktisadi ve İdari Bilimler Fakültesi Dergisi, 27(1), 113-141.

Sınıksaran, E., and Aktütün, A. (2004). Karl Popper'ın yanlışlama kuralı hipotez testleri ve iktisat. İktisat Fakültesi Mecmuast, 54(2), 47-60.

Tanyaş, B. (2014). Nitel araştırma yöntemlerine giriş: genel ilkeler ve psikolojideki uygulamaları. Eleştirel Psikoloji Bülteni, (5), 25-38.

Yıldırım, A., and Şimşek, H. (2016). Sosyal bilimlerde nitel araştırma yöntemleri (10th ed.). Ankara: Seçkin Yayıncılık 